\title{
Towards Sustainable IT by Teaching Governance Practices for Inter-Organizational Dependencies
}

\author{
Carl Stolze, Matthias Boehm, Novica Zarvić, and Oliver Thomas \\ Katharinenstraße 3, 49074 Osnabrück \\ Tel.: +495419694810 \\ \{carl.stolze, matthias.boehm, novica.zarvic, \\ oliver.thomas \} @uni-osnabrueck. de
}

\begin{abstract}
The issue of sustainability has been among the top concerns of IT practitioners for some time now. Although sustainability of and through IT can only be reached if all stakeholders work together, current teaching and on-thejob training approaches do not provide the required understanding of how to govern the cooperation. Furthermore, there is a general gap between IS academia and practice regarding skill teaching, stakeholder informing and contributions towards sustainable business practices. In this paper, we adopt a design science research methodology to develop and evaluate a first approach to close this threefold gap.
\end{abstract}

Keywords: Governance, Sustainability, Green IT, Alignment, Teaching, Inter-Organizational Dependencies, Information Technology.

\section{Introduction}

Today's business and information technology (IT) environment is more dynamic and competitive than ever before (LaFrance 2010; Lee et al. 2002; Wingreen et al. 2009). Increasing public awareness for the environmental impact of IT as well as rising energy prices made sustainability become one of the top concerns for the IS/IT function of many organizations - it is even viewed as a competitive factor now (Sarkar and Young 2009; Vykoukal et al. 2009). Practitioners and academics alike have been discussing mainly energy consumption-related questions under the term Green IT for some time (McBrayne 2007; Watson 2010). In more recent discussions, the focus started to shift towards a broader understanding of sustainable information systems (IS) - including its design as well as leveraging the design of IS for a more sustainable enterprise (El-Gayer and Fritz 2006; Gartner Inc. 2009; Melville 2010; Woodruff and Mankoff 2010).

Creating such an environment of IT that is sustainable in itself (Sustainable IT) as well as fostering sustainability throughout the organization (Sustainable through IT) requires the integration and informing of numerous stakeholders inside and outside one's organization (Watson 2010). Therefore, we are dealing, additionally and next to the intra-organizational relationships, with inter-organizational relationships (Bachmann and van Witteloostuijn 2009). Factors such as technological and organizational 
change, globalization, climate change and a sustainability movement create an environment, in which companies and individuals have to cope with changing and differing approaches, requirements and technologies as well as unprecedented volatility in their work, required knowledge and skills (Lee et al. 2002; Osorio and Bulchand 2011; Schambach and Blanton 2002). Especially IS professionals, and in particular those at the beginning of their career, have to strive for permanent personal growth regarding skill and knowledge (Schambach and Blanton 2002).

The traditional role of universities has been the fostering of critical thinking without adherence to specific approaches (Adams and Zanzi 2004). Within a specific discipline, such as Information Systems, the task is to create knowledge (through research) and distribute knowledge (through teaching) (Gill and Bhattacherjee 2009). It is reported that there is a threefold gap between IS academia and IS practice: First, knowledge and skills required for IS jobs are not taught satisfactorily (Lee et al. 2002). Second, IS research is not sufficiently informing its key stakeholders (Gill and Bhattacherjee 2009), so that methods and approaches for enabling a better knowledge transfer between practice and academia are required (Wilson and Guzdial 2010). And third, the discipline's contribution towards sustainable business practices has been described as insufficient so far (Melville 2010; Watson 2010). Although there are plenty of IS curricula for undergraduate and graduate degrees in Information Systems (Downey et al. 2008; Plice and Reinig 2009; Topi et al. 2010), integrated and holistic academic programs for on-the-job training of IS professionals are missing - especially ones that also integrate questions of inter-organizational relationships (IORs) and sustainability.

\section{Research Method}

In this paper, we aim at developing one possible conception to overcome the before described threefold problem adopting IS design science research (DSR) methodology. DSR aims at improving the environment with the help of theory and knowledge for action (Hevner et al. 2004; Carlsson et al. 2010; Kuechler and Vaishnavi 2008). We understand DSR in the sense that the development of practically applicable knowledge for designing and realizing diverse IS should be the outcome of the research endeavor (Carlsson et al. 2010; Kuechler and Vaishnavi 2008). Good DSR should start with the identification and presentation of relevant problems in an actual application domain (Hevner 2007; Kuechler and Vaishnavi 2008). This relevance has to be balanced with rigor, whilst following a circle of design and evaluation to propose a problem-solving novel contribution (Hevner 2007; Kuechler and Vaishnavi 2008).

In the course of this paper, we first introduce the concept of IORs together with the need for their governance and how sustainability efforts create new IORs. The relevance of our research is supported by a survey regarding IT governance and IORs. Afterwards, we explore currently offered on-the-job training courses in the IS domain as a basis for our own conception. The presentation of the results begins with an illustration of the requirements for an integrated and holistic teaching approach. Based on this, our approach with a specific focus on inter-organizational relations in the context of sustainable IT is presented. After we will have evaluated a first course in form of an experiment, we discuss the main findings, limitations and give an outlook. 


\section{Background}

\subsection{Inter-Organizational Relations and IT Governance}

Throughout a single enterprise, departments and individuals are dependent on each other at various levels. For instance, in order to fulfill follow-up activities inside an intra-organizational business process, we often depend on an outcome provided by a colleague (Thompson 1962). Also, we can depend on the support that IT is supposed to provide us. The IT itself must be well-aligned with the business processes and the overall business strategy of the company (Henderson and Venkatraman 1993), resulting in new interdependencies that may influence the overall outcome. Therefore, interdependencies are a very important aspect and omnipresent in our working life (Kanter 1994). As a consequence they need to be managed and coordinated to assure the success of any business (Malone and Crowston 1994). When cooperating or collaborating with other companies and stakeholders (Kumar and van Dissel 1996), interdependencies are inter-organizational relationships (IORs) - business arrangements that cross the boundaries of an individual enterprise (Bachmann and van Witteloostuijn 2009). This in turn makes the challenge of managing and coordinating such inter-organizational collaborations (Chi and Holsapple 2005) and specifically the resulting inter-organizational dependencies (IODs) more complicated, because we firstly do not have a single decision point in such network arrangements and, secondly, we are dealing with dependencies that comprise different individual enterprises and thus have an inter-organizational character.

Since the late 1990s the concept of IT Governance emerged as the distinct conceptualization of steering the use of IT within a company (van Grembergen 2010). Business-IT Alignment and IT Governance can be understood as complementary and deeply intervened concepts (Tiwana and Konsynski 2010; Weill and Ross 2004). Most authors share the common understanding that IT Governance is the top management concern of controlling the strategic impact of IT and its value delivery to the business (Becker et al. 2009; Simonsson and Johnson 2006). These facts have among others - an enormous impact for both Business-IT Alignment and IT Governance activities (Zarvić et al. 2010a), which need to be viewed as interrelated and coherent research topics in the IS research and teaching domain.

According to de Haes and van Grembergen (2004) all relational mechanisms are a very important aspect of governance. The biggest problem to be avoided is that business and IT do not understand each other and/or do not complement each other's work. In order to achieve effective IT Governance "two-way communication and a good participation/collaboration relationship between business and IT people" (de Haes and van Grembergen 2004) is needed. Hence, we are dealing with communication and collaboration issues. We can distinguish with respect to these two issues ex-ante and ex-post relational mechanisms, because several mechanisms should already be planned before IOR formation, and later monitored, controlled and adapted during the operation of an IOR (Dekker 2004). In Table 1, an overview on main relational mechanisms for inter-organizational governance is given. 
Table 1. Relational mechanisms for inter-organizational governance

Two-way communication
Collaboration relationship

- $\quad$ Setting IOR goals (Dekker 2004).

- $\quad$ IOR formation and partner selection on the basis of IODs (Zarvić et al. 2010b)

- $\quad$ Strategic alignment maturity model (Luftman 2005).

- ICoNOs MM: IT-enabled Collaborative Networked Organizations Maturity Model (Santana Tapia 2009).

- $\quad$ IT Governance maturity model

(IT Governance Institute 2010).

Nevertheless, according to Camarinha-Matos (2007), the trend of forming Collaborative Networks will further continue - especially in light of sustainability endeavors. This claim has been confirmed in a survey about IT governance and interorganizational relationships within our global research network. Based on completed questionnaires $(n=18)$, equating to a response rate of $21.7 \%$, we assessed the relevance of the investigated topic among researchers and practitioners alike to be sure to have identified a problem of interest for multiple entities (Offermann et al. 2009). The respondents came from Germany, The Netherlands, Poland, Brazil, Spain, Slovenia, Italy and USA. Half of the respondents are from research and academia and the other half works in consulting, logistics or IT-related industries, therefore answers are not biased by a specific industry affiliation. A proxy for competence of the respondents are their academic degrees: $16.6 \%$ hold a doctoral degree, $66.7 \%$ a Master degree (or equivalent), $11.2 \%$ a Bachelor degree, and only $5.5 \%$ of the respondents do not hold any academic degree.

Table 2 shows the main empirical results of our small survey with the five most important statements. Our questionnaire is based on a simple four-level Likert scale for the answers with values from 1 to 4 . A value of 1 is used to represent complete disagreement whilst a value of 4 stands for complete agreement with a statement. 
Table 2. Survey results about IT governance and IORs

\begin{tabular}{lll}
\hline$\#$ & Statement & Average \\
\hline 1 & $\begin{array}{l}\text { IT Governance is not important for inter-organizational } \\
\text { relationships }\end{array}$ & 1.13 \\
2 & $\begin{array}{l}\text { Inter-organizational relationships need specific IT governance } \\
\text { structures. }\end{array}$ & 3.17 \\
3 & $\begin{array}{l}\text { Business-IT Alignment is much more difficult in an } \\
\text { inter-organizational context than in individual companies. }\end{array}$ & 3.33 \\
4 & $\begin{array}{l}\text { Inter-organizational dependencies (e.g. relying on business } \\
\text { partners and their processes and systems) represent an important } \\
\text { aspect with respect to IT Governance. }\end{array}$ & 3.06 \\
& $\begin{array}{l}\text { Do you think the importance of inter-organizational relationships } \\
\text { and dependencies will increase in the future? }\end{array}$ & 3.39 \\
\hline
\end{tabular}

The respondents negate statement 1, as negative statement; therefore IT Governance should be seen as absolutely important for IORs. Answers to the second and fourth statement outline the intervened nature between IT Governance and IORs and IODs respectively. Together with statement 3 we draw the conclusion that specifically designed and adjusted Business-IT Alignment and IT Governance concepts have to be utilized for inter-organizational collaboration arrangements, especially for the integration of the different stakeholders in a sustainable IT arrangement. Statement 5, the importance of inter-organizational relationships and dependencies in the future, received a high median value as well, which is no surprise when the trend towards a more sustainable IT together with its new IORs is looked at.

\subsection{Sustainable IT Creating IORs and IODs}

The steady increase in computing power required an advancement in energy supply and cooling of IT infrastructure, thereby directing the focus of Green IT to technical components (Brooks et al. 2010; Ehrenfeld 2001; McBrayne 2007; Melville 2010; Schmidt et al. 2010; Watson 2010). By doing so, the sustainable development of the enterprise as a whole was often neglected. To make matters more complicated, in most organizations outside the IT industry there is a lack of expertise regarding the planning, realization and operation of IT infrastructure (Farhoomand 2005; McBrayne 2007; Schmidt et al. 2010), since they usually obtain IT as well as the related heating and air-conditioning equipment from specialized vendors. Besides facility management and energy, suppliers also provide products and services needed to run a company's IT infrastructure. To overcome these limitations towards a truly sustainable IT, an integrated approach is needed, an approach that integrates all stakeholders and thereby creates inter-organizational relations and dependencies (Melville 2010; Schmidt et al. 2010; Vykoukal et al. 2009). An example for such relations and dependencies is depicted in Fig. 1. 


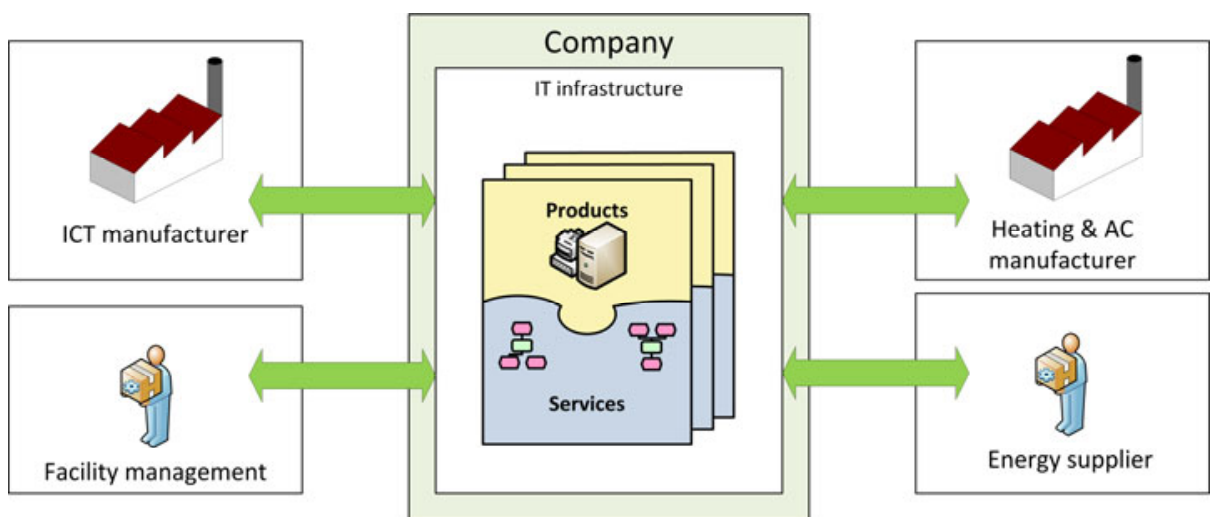

Fig. 1. Inter-organizational relations and dependencies for sustainable IT infrastructure

The focal company's IT infrastructure in the center of Fig. 1. consists of products and services. Although not explicitly shown, as those are intra-organizational dependencies, the IT and its infrastructure provide and consume services to and from the rest of the company. The depicted four dependencies and relations link the company with the ICT manufacturer, heating and air-condition manufacturer, a facility management company and last but not least with the energy supplier. All four provide vital parts for the IT infrastructure and therefore need to be included in every integration attempt towards more sustainability. Also, this integration creates a higher degree of interdependency as suppliers cannot be replaced as easy as before.

\subsection{Training Approaches}

As any successful change, the endeavor towards a more sustainable IT has to go through the head of any employee involved - first, to create awareness and understanding to eventually change behavior (Jenkin et al. 2010). This requires acquisition of knowledge and skills for present tasks - or in a simple word: training. According to Fitzgerald (1992), training is a tool to help individuals contribute to the organization and be successful in their current positions. Therefore, it is a means to an end. One can further discern general training and specific (on-the-job) training (Nguyen et al. 2010). In any case, it should result in changed behavior, meaning the newly acquired knowledge and skills are actually accompanied by the necessary competences to be applied (Fitzgerald 1992; Osorio and Bulchand 2011).

Literature describes different training programs for different purposes within the IT/IS domain (cf. Table 3). A common characteristic is the separation of required knowledge and competencies into two different segments. On the one side, there are technical skills, such as business and IT skills. Those should be taught. On the other side are personal skills, like the interpersonal skill of collaboration. It is noticeable that foundational IT skills and interpersonal skills are named most in literature. Although there are plenty of IS curricula for undergraduate and graduate degrees in Information Systems (Downey et al. 2008; Plice and Reinig 2009; Topi et al. 2010), integrated and holistic academic programs for on-the-job training of IS professionals are missing. 
Table 3. Selected Teaching Approaches in Literature

\begin{tabular}{|c|c|c|c|c|c|c|c|c|c|}
\hline \multirow[b]{2}{*}{ Author(s) } & \multicolumn{4}{|c|}{ Technical skills } & \multicolumn{5}{|c|}{ Personal skills } \\
\hline & 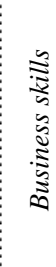 & 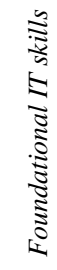 & 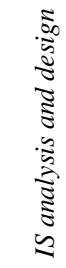 & 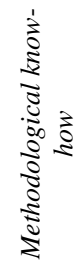 & 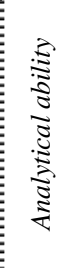 & 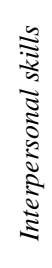 & 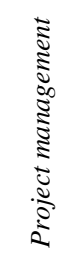 & 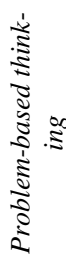 & 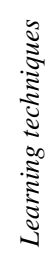 \\
\hline Smid (2001) & $\mathrm{x}$ & & $\mathrm{x}$ & $\mathrm{x}$ & & & & $\mathrm{x}$ & $\mathrm{x}$ \\
\hline Mohe (2006) & & $\mathrm{x}$ & & $\mathrm{x}$ & $x$ & $\mathrm{x}$ & $\mathrm{x}$ & $\mathrm{x}$ & \\
\hline Plice and Reinig (2009) & & $\mathrm{x}$ & & & & $\mathrm{x}$ & & & \\
\hline Luftman and Ben-Zvi (2010) & $x$ & $\mathrm{x}$ & & & & $\mathrm{x}$ & & & \\
\hline Pratt et al. (2010) & & $\mathrm{x}$ & & $\mathrm{x}$ & $x$ & $\mathrm{x}$ & & & $\mathrm{x}$ \\
\hline Gallagher et al. (2010) & & $\mathrm{x}$ & $\mathrm{x}$ & & & $\mathrm{x}$ & $\mathrm{x}$ & $\mathrm{x}$ & \\
\hline
\end{tabular}

Next to the general descriptions of required knowledge and competencies as depicted in Table 3, there are more concrete lists of modules that IS courses should offer (cf. for example (Kim et al. 2006; Smith and McKeen 2006; Topi et al. 2010)). Modules on information management, corporate (IT) governance, IS strategy, security and other soft skills are named for example. Gorman (2010) criticizes that these approaches create a gap between "hard" IT training and "soft" HR skills training. In order to overcome this problem, Plice and Reinig (2009) investigated the requirements of an IS program (for undergraduate or graduate students) from an IT professional's point of view:

- Opportunities for the development of interpersonal communications skills.

- Coverage of a broad range of technical topics rather than in-depth coverage of specific hardware or software environments or programming languages.

- Acquisition of a core competency in systems development, project management as well as business and managerial skills.

\section{Current Offers for on-the-Job Training}

To assess the currently offered programs for on-the-job training, we examined 33 programs in the IT management area within German-speaking Europe. Although they all cover the same area, their organization and content as well as targets are diverging. Some claim that graduates will be able to plan, sell and implement complex IT projects or determine the organizational setting. In other courses, the focus is more on the technical and data processing level. And even others emphasize a scientific approach, independent working or the support for improving soft skills. However, most aim at qualifying successful future businesses leaders.

A selection of some characteristics of the investigated offerings can be found in Table 4. Overview on the Investigated Offerings. We found (out) that in more than half of the courses relatively recent graduates with one to five years of professional experience are targeted. Only $36.6 \%$ of the offers want to reach middle management. The range of fees varies from $€ 2,000$ to more than $€ 50,000$. However, the fees can 
be grouped into three clusters (low, medium and high fees). When it comes to the persons, who actual conduct the teaching, mainly professors are in charge. Only two courses have been found, that also involve practitioners. As certification, in $69.7 \%$ of the cases a classical master degree is awarded and $21.2 \%$ promote a MBA degree. Other certificates are only given by three courses. In $69.7 \%$ of the cases, a written examination is to achieve one of the certificates. Other forms of methods are rarely utilized. From this overview on existing offerings, one can see the necessity for offering on-the-job training courses, that are conducted by professors and practitioners, offer a certain certificate and utilize appropriate teaching methods by carefully choosing an appropriate fee system.

Table 4. Overview on the Investigated Offerings

\begin{tabular}{llll}
\hline Variable & Value & Absolute & Percent \\
\hline Target group & $\begin{array}{l}\text { Graduates with 1-5 years of } \\
\text { professional experience }\end{array}$ & 19 & \\
& Professionals & & $57.6 \%$ \\
& management) & & \\
& n/a & & $36.4 \%$ \\
Fee & $€ 2,000-10,000$ & 2 & $6.1 \%$ \\
& $€ 10,001-30,000$ & 8 & $24.2 \%$ \\
Tutor & € 30,001-50,670 & 12 & $36.4 \%$ \\
& n/a & 3 & $9.1 \%$ \\
Certificate & Professors & 10 & $30.3 \%$ \\
& Professors and practitioners & 24 & $72.7 \%$ \\
n/a & 2 & $6.1 \%$ \\
& Master (of Science or of Arts) & 23 & $21.2 \%$ \\
& MBA & 7 & $69.7 \%$ \\
& Other certificate & 3 & $21.2 \%$ \\
& Written examination & 23 & $9.1 \%$ \\
& Presentation, group work & 3 & $69.7 \%$ \\
& Participation & 1 & $9.1 \%$ \\
& n/a & 6 & $3.0 \%$ \\
& & & $18.2 \%$ \\
\hline
\end{tabular}

Altogether, more than 60 different modules have been found in the 33 investigated curricula. As many of them cover similar topics and issues, each unit has been investigated according to its content, outline and objectives. Finally, the two kinds of modules (methodology and personal skills), which have been described in literature already, have also been discovered in this study. The methodological modules can be grouped further into seven units, namely Management in the Information Age, IS Fundamentals, IT Consulting, Enterprise Architecture Management, Business Process Management, Managing Security, Compliance and Risk as well as Sustainability and Ethics. The personal skill modules, which have been found, are grouped into Interpersonal skills and Project Management skills.

Based on these findings, one can derive requirements for an integrated teaching approach. The following points, which serve as the basis for our approach, have to be covered: 
- Academia and practice knowledge exchange: It is important for any training, but especially for courses within highly dynamic environment like IT management to transfer knowledge from academia into practice and vice versa. Therefore, practitioners also have to be invited to teach scientists as well as other practitioners on specific topics.

- Structured procedure: Because of the diversity of offerings, certificates and organizational issues, IT training offerings have to be structured according to widely accepted procedures in order to ensure a useful and practicable training effect.

- Concentration on relevant issues: Based on defined objectives and the target group, the selection of relevant modules is vital. But also their connection with each other should be mentioned and outlined. This is especially true for teaching the governance of IORs in the context of sustainable IT.

\section{Integrated Approach for Teaching}

The aim of our approach is to derive and implement a program that captures a holistic view on relevant issues within the field of IT management with a special attention towards sustainable IT. The interaction between academia and practice is most important in order to ensure the theoretical foundation and the practical application of the taught material. For this objective, we follow the model shown in Fig. 2. which follows the ideas of collaborative practice research (Mathiassen 2002). Accordingly, practitioners and researches work together in order to share their information to the participants while both receive feedback on their actions. From the perspective of the participants, they do not only receive information on current technology and trends, but they also get to know others who are in similar situations as they are. Networking between them is therefore a side effect of our approach. Hence, this model ensures the knowledge transfer between academia and practice.

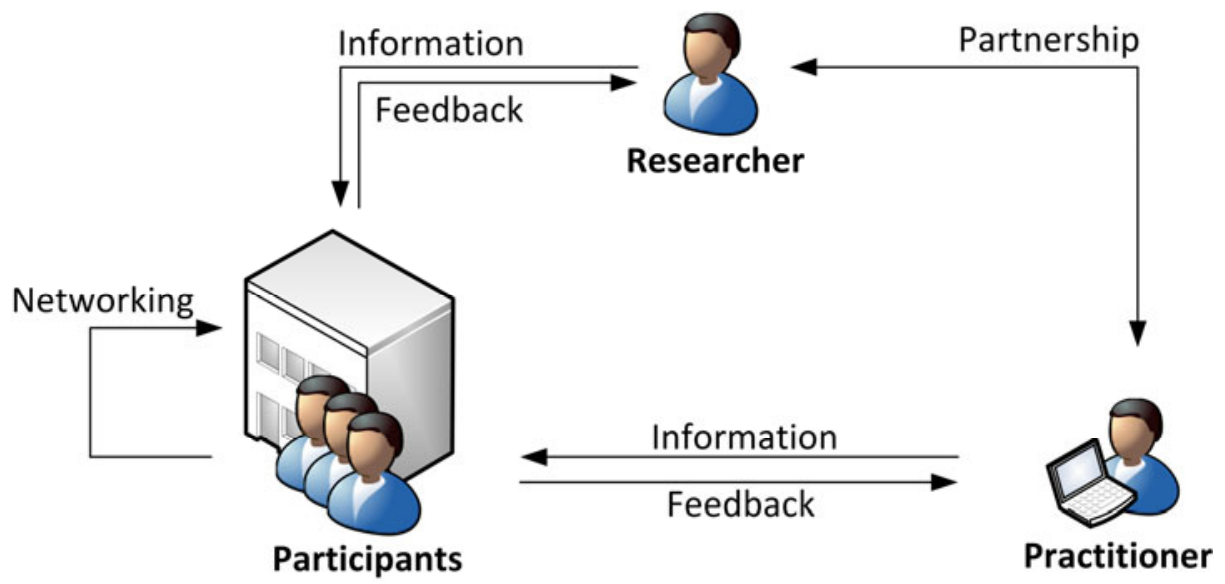

Fig. 2. Model of Researcher-Practitioner Collaboration 


\subsection{Framework and Modules}

The framework of our approach is structured in form of a house (cf. Fig. 3.). The essential support functions of infrastructure management and teaching staff management build the base. Together with strategy at the top, evaluation and evolution as well as the operational management can be found in the roof. These activities ensure the successful implementation and the adherence to legal, political or other external requirements. Within the body of the house, the core modules can be found in two groups. First, methodology courses cover functional and technical content in the seven modules found during the assessment of existing offerings. Second, in the personal skills modules, interpersonal skills, leadership and conflict management as well as project management have to be taught.

These core activities respectively modules are framed with the relevant stakeholders. On the left-hand side, participants and tutors can be seen as the input side. On the right-hand side, companies, especially small and medium sized enterprises (SME), consulting firms and universities profit from the outcome of the training.

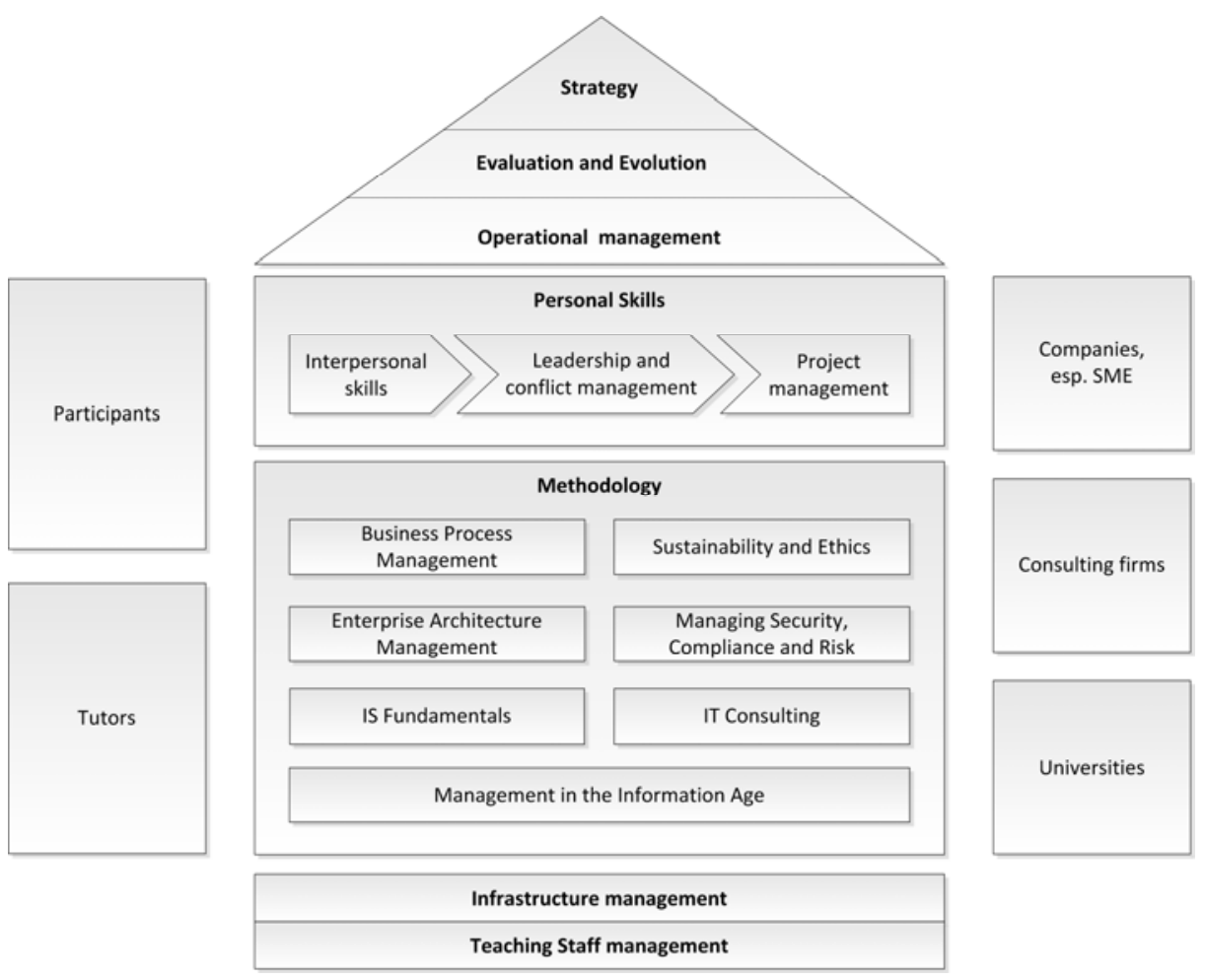

Fig. 3. Framework of the Integrated Approach 
Table 5. Overview on the Methodology Modules

\begin{tabular}{|c|c|c|}
\hline$\#$ & Module (Abbr.) & Content \\
\hline 01 & $\begin{array}{l}\text { Management in the } \\
\text { Information Age (MIA) }\end{array}$ & $\begin{array}{l}\text { - Internet economics } \\
\text { - Management basics } \\
\text { - English business language skills } \\
\text { - Inter-organizational relations (IORs) }\end{array}$ \\
\hline 02 & IS Fundamentals (ISF) & $\begin{array}{l}\text { - IT basics and IT controlling } \\
\text { - Enterprise software, like enterprise } \\
\text { resource planning (ERP) } \\
\text { - Foundations of knowledge management, } \\
\text { business intelligence and data } \\
\text { warehouses, data analytics }\end{array}$ \\
\hline 03 & $\begin{array}{l}\text { Enterprise Architecture } \\
\text { Management (EAM) }\end{array}$ & $\begin{array}{l}\text { - IT governance and IT strategy } \\
\text { - Business-IT alignment } \\
\text { - IT service management } \\
\text { - Change management }\end{array}$ \\
\hline 04 & $\begin{array}{l}\text { Business Process Management } \\
\text { (BPM) }\end{array}$ & $\begin{array}{l}\text { - Approaches } \\
\text { - Methods }\end{array}$ \\
\hline 05 & IT Consulting (ITC) & $\begin{array}{l}\text { - Business foundations: marketing, } \\
\text { organization, accounting, founding and } \\
\text { investment } \\
\text { - Collaborative business, mergers and } \\
\text { acquisitions } \\
\text { - Customer relationship management } \\
\text { (CRM) } \\
\text { - IT cost management }\end{array}$ \\
\hline 06 & $\begin{array}{l}\text { Managing Security, } \\
\text { Compliance and Risk (MSCR) }\end{array}$ & $\begin{array}{l}\text { - IT security } \\
\text { - IT legislation and IT contracts } \\
\text { - IT risk management }\end{array}$ \\
\hline 07 & Sustainability and Ethics (SE) & $\begin{array}{l}\text { - Green IT } \\
\text { - Management ethics and social aspects of } \\
\text { information management } \\
\text { - Intercultural studies }\end{array}$ \\
\hline
\end{tabular}




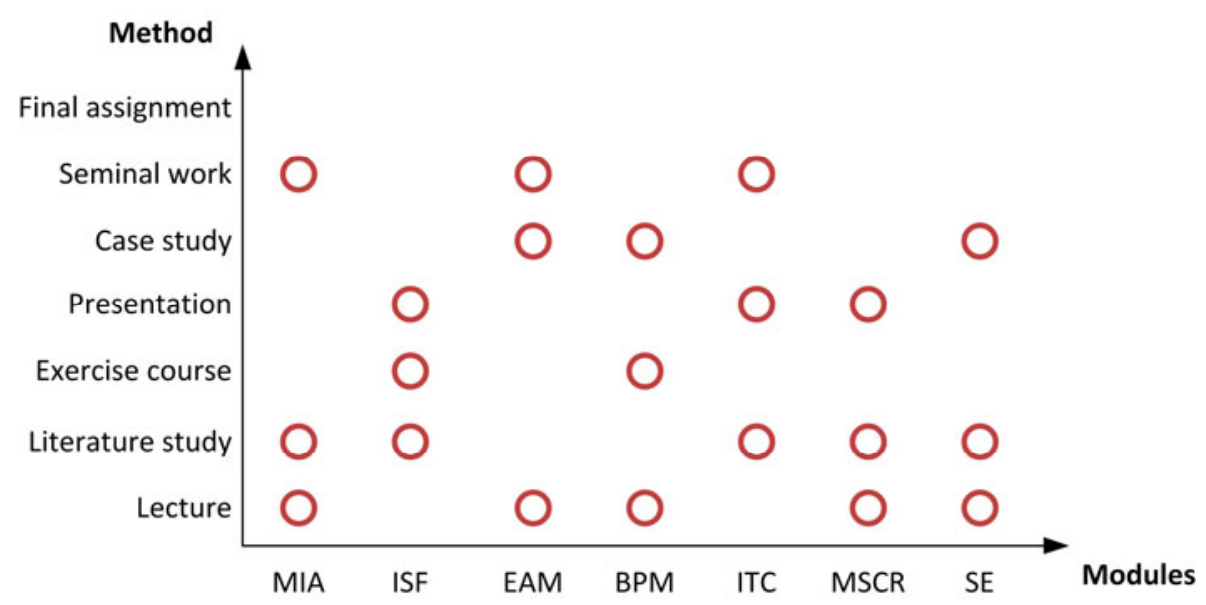

Fig. 4. Teaching Methods for each Methodological Module

In order to get a deeper insight into the actual content that is taught within the course, Table 5 gives an overview of the content of the methodology modules. For each module, a specific set of teaching methods, like case study teaching (Hackney, McMaster, and Harris 2003), is required (Beard and McPherson 1996). The assignment of methods for modules is depicted in Fig. 4. For each module (x-axis), specific methods (y-axis) have been chosen, which best facilitate learning (Beard and McPherson 1996).

Before discussing the holistic approach to teach IT governance practices for IORs in the context of sustainable IT, the personal skills modules should be briefly explained. A module regarding project management has to be included because projects are a major form of organization in IT. The interpersonal skills module teaches techniques for presentation and moderation. Although the leadership and conflict management module has not been found explicitly in literature, we think that these skills are crucial for managers on the way to a sustainable enterprise. In opposite to the methodological modules, the personal skills modules are taught in block seminars accompanied by two trainers for two days while a maximum of fourteen participants is allowed to attain one seminar. This practice ensures that every participant will learn as much as possible from the seminar.

\subsection{Description of the Concept to Teach Governance Practices for IORs in the Context of Sustainable IT}

A topic such as governance practices for IORs in the context of sustainable IT spans across multiple aspects and therefore modules in our framework. Therefore, we describe in Table 6 how such an interdisciplinary and important topic can be taught with the help of our framework. In the following, the content of the accountability class (class no. 5) is used to evaluate our approach. 
Table 6. Description of the Interdisciplinary Module

Governance Practices for IORs in the Context of Sustainable IT

Description The global trend towards more sustainability in business practices calls also for action in the IT. To tackle issues of sustainability persistent and consistent collaboration with all involved stakeholders is necessary. In the context of IT infrastructure, this involves ICT manufacturers, air-condition suppliers as well as power utilities and facility management services. Steering of these interorganizational relations requires governance practices tailored to the area.

Underlying 1. The networked economy (Management in the Information Age classes

\section{(MIA) module)}

2. The call for more sustainability (Sustainability and Ethics (SE) module)

3. Sustainable IT - from Green IT to sustainability through IT (SE module)

4. Aligning business \& IT (Enterprise Architecture Management (EAM) module)

5. Accountability and IT governance practices (EAM module)

Learning objectives
- Being aware of the issues of sustainability.

- Enabling the design of sustainable IT.

- Understanding accountability as important aspect of sustainability and governance.

- Being able to design and implement governance practices on IORs that foster sustainable behavior.

\section{Evaluation and Results}

To test our approach, we conducted an experiment in a post-graduate teaching assignment on Enterprise Architecture Management - namely in the underlying class 5 "accountability assignment". The assignment of accountability to executive roles and the fulfilling persons is one of the key elements of establishing IT Governance practices. Magnusson stated recently that IT Governance is carried out by top executives (Magnusson 2010). We therefore considered in our experiment about an accountability matrix only top executives (CxOs) because "IT Governance should be an integral part of an enterprise governance and, in this respect, a primary concern of the board of directors that is responsible for governing the enterprises" (de Haes and van Grembergen 2004). IT Governance implementations should therefore not be an issue only within IT, but business executives should take a leading role as well (van Grembergen 2010).

Seven teams of two to three students were formed and given about 45 minutes of time at their disposal to assign different job descriptions to predefined enterprise architecture levels, whereby each enterprise architecture level was represented by one dependency category representing a generalization of diverse layered architecture style frameworks (Zarvić et al. 2010a). The main focus of the experiment was a 
detailed competency mapping of selected job descriptions according to the so-called competence pyramid (cf. Wieringa et al. 2009). In addition, the post-graduate students also treated the aspect of responsibility of the selected job descriptions as well as of top executive roles on the basis of the RASCI model (Paul et al. 2010). The results of accountability spans for the different $\mathrm{CxOs}$ are depicted Fig. 5.

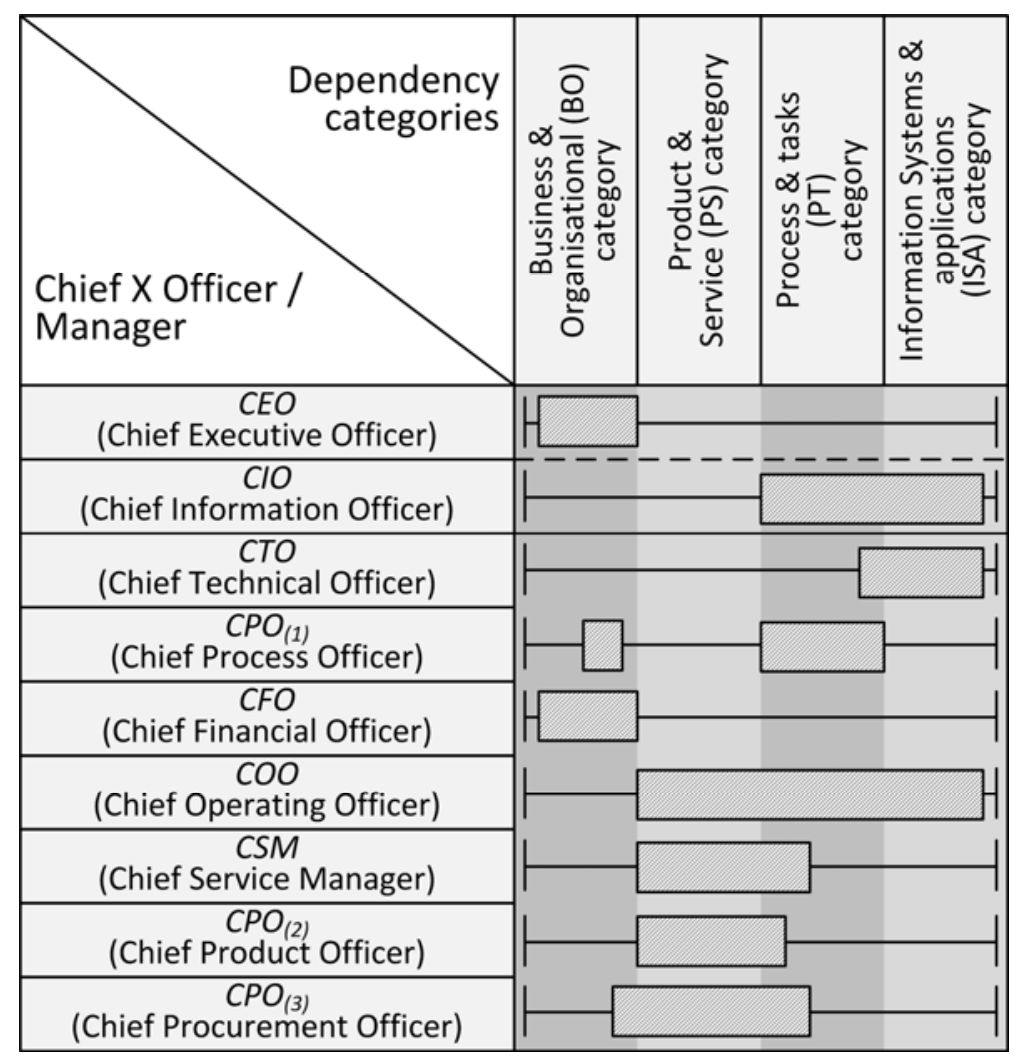

Fig. 5. Accountability Matrix for different top executives

As the resulting accountability matrix lines out, we can conclude with respect to the design of governance practices in the context of sustainable IT that these students understood the underlying concepts of accountability, IT governance and accountability assignment and their relations quite well. Also, the different accountability span of different roles was quite well understood.

\section{Discussion and Conclusion}

In our research, guided by the DSR paradigm, we conceptualized an integrated and holistic approach for teaching post-graduate professionals. Our approach as a 
whole is an artifact that consists of several distinct parts in its design: The model of researcher-practitioner collaboration aims at facilitating and improving exchange between academia and practice. It is the underlying rationale for the design as well as the structure for enabling interaction between the stakeholders. The framework as second model is the visual trademark representation of our approach. Furthermore, we presented the description of how to teach the interdisciplinary topic of governance practices for inter-organizational relationships in the context of sustainable IT as a specific content description within this framework. In this sense our holistic approach as an artifact enables human action and is thereby following the DSR paradigm (Hovorka 2010).

Nonetheless, there are limitations in the design process, the artifact and the evaluation. Our design process was triggered by the realization of the fact that sustainability endeavors might create more complex IODs and thereby IORs. From a previously conducted survey regarding IT governance and IODs we knew they would become even more important. As any change for the better has to go through the heads of the involved stakeholders, we looked at how to change their behavior and found that teaching them in the form of on-the-job training is an appropriate way. Therefore, we are certain that we tackle a relevant problem in the DSR sense (Kuechler and Vaishnavi 2008). Based on this insight, we analyzed existing offerings regarding on-the-job training and derived requirements for our own approach. Whilst building on existing knowledge is an important part of DSR, our selection of examined offerings could only cover a certain set and thereby creating a certain context. This is even more obvious for the evaluation: First, we could only test a portion of the whole approach so far. Therefore, we could not verify if the intended effects will match the later experienced ones or how this varies between different actors (cf. (Hedström 2003) for those perspectives in the context of computerization). Second, we cannot objectively prove that our approach is the single best one or the only truth to be revealed as our results are always subject to interpretation (Heriksen and Kautz 2006). Nevertheless, we believe our approach as a whole is an artifact enabling human action and being from our interpretation better than existing ones (Hovorka 2010).

In conclusion, we believe our approach can help as a model to enable both research and practice to exchange and extend their cooperation whilst pursuing the aim of sustainable IT. For the future, we aim at constantly evaluating and iteratively evolving the approach based on feedback - especially in light of changing educational demands and environments (Osorio and Bulchand 2011). Thereby, we hope to contribute, one step at a time, towards a better use of IT to build a sustainable future.

Acknowledgement. This paper was partially written in the context of the research project IMUCON which is funded by the European Regional Development Fund (ERDF). The authors are pleased to acknowledge the support by ERDF and all involved project partners. Furthermore, we would like to thank the anonymous reviewers for their insightful and helpful comments. 


\section{References}

Adams, S.M., Zanzi, A.: Academic development for careers in management consulting. Career Development International 9(6), 559-577 (2004)

Bachmann, R., van Witteloostuijn, A.: Analyzing Inter-Organizational Relationships in the Context of Their Business Systems. European Societies 11(1), 49-76 (2009)

Beard, C., McPherson, M.: Design and Use of Group-based Training Methods. In: Wilson, J.P. (ed.) Human Resource Development: Learning \& Training for Individuals \& Organizations, pp. 285-306. Sterling, London (1996)

Becker, J., Pöppelbuß, J., Stolze, C., Cyrus, A.: Developing a Framework for IT Governance in the Post-Merger Integration Phase. In: Proceedings of the 17th European Conference on Information Systems (ECIS 2009), Verona, Italy, pp. 3137-3149 (2009)

Brooks, S., Wang, X., Sarker, S.: Unpacking Green IT: A Review of the Existing Literature. In: Proceedings of AMCIS 2010, Paper 398 (2010)

Camarinha-Matos, L.: Collaborative Networks in Industry - Trends and Foundations. In: Cunha, P., Maropoulos, P. (eds.) Digital Enterprise Technology - Perspectives and Future Challenges, pp. 45-56. Springer, New York (2007)

Carlsson, S.A., Henningsson, S., Hrastinski, S., Keller, C.: Socio-technical IS design science research: developing design theory for IS integration management. Information Systems and e-Business Management 9(1), 109-131 (2010)

Chi, L., Holsapple, C.W.: Understanding computer-mediated interorganizational collaboration a model and framework. Journal of knowledge Management 9(1), 53-75 (2005)

De Haes, S., van Grembergen, W.: IT Governance and Its Mechanisms. Information Systems Control Journal (1) (2004)

Dekker, H.: Control of inter-organizational relationships: evidence on appropriation concerns and coordination requirements. Accounting, Organizations and Society 29(1), 27-49 (2004)

Downey, J.P., McMurtrey, M.E., Zeltmann, S.M.: Mapping the MIS Curriculum Based on Critical Skills of New Graduates: An Empirical Examination of IT Professionals. Journal of Information Systems Education (19) (2008)

Ehrenfeld, J.: Designing 'Sustainable' Product/Service Systems. In: Proceedings of International Symposium on Environmentally Conscious Design and Inverse Manufacturing, December 11-15. IEEE Computer Society, Los Alamitos (2001)

El-Gayer, O., Fritz, B.D.: Environmental Management Information Systems for Sustainable Development - A Conceptual Overview. Communications of the AIS (17), article 34 (2006)

Eschenbächer, J., Zarvić, N., Thomas, O., Thoben, K.-D.: Measuring and Evaluating Communication Intensities in Collaborative Networks. In: Camarinha-Matos, L.M., Boucher, X., Afsarmanesh, H. (eds.) PRO-VE 2010. IFIP AICT, vol. 336, pp. 527-536. Springer, Heidelberg (2010)

Farhoomand, A.: Managing (e)business transformation: a global perspective. Palgrave Macmillan, Basingstoke (2005)

Fitzgerald, W.: Training Versus Development. Training \& Development 46(5), 81-84 (1992)

Gallagher, K.P., Kaiser, K.M., Simon, J.C., Beath, C.M., Goles, T.: The Requisite Variety of Skills for IT Professionals. Communications of the ACM 53(6), 144-148 (2010)

Gartner Inc. Gartner Identifies the Top 10 Strategic Technologies for 2010 (2009), http: / / www.gartner. com/it/page.j.sp?id=1210613 (retrieved 2010-08-07)

Gill, G., Bhattacherjee, A.: Whom Are We Informing? Issues and Recommendations for MIS Research from an Informing Sciences Perspective. MIS Quarterly 33(2), 217-235 (2009)

Gorman, M.F.: A Case Study in Effectively Bridging the Business Skills Gap for the Information Technology Professional. Journal of Education for Business 86(1), 17-24 (2010) 
Hackney, R., McMaster, T., Harris, A.: Using Cases As A Teaching Tool In IS Education. Journal of Information Systems Education 14(3), 229-234 (2003)

Hedström, K.: The Socio-Political Construction of CareSys. In: Daamsgard, J., Henriksen, H.Z. (eds.) Networked Information Technologies - Diffusion and Adoption, pp. 1-18. Kluwer Academic Publishers, New York (2003)

Henderson, J.C., Venkatraman, N.: Strategic Alignment: Leveraging Information Technology for Transforming Organisations. IBM Systems Journal 32(1), 272-284 (1993)

Heriksen, H.Z., Kautz, K.: An Analysis of IFIP TC 8 WG 8.6. In: Avison, D., Elliot, S., Krogstie, J., Pries-Heje, J. (eds.) The Past and Future of Information Systems: 1976-2006 and Beyond, Santiago, Chile, August 21-23. IFIP 19th World Computer Congress, TC-8, Information System Stream, pp. 143-152. Springer, Boston (2006)

Hevner, A.R.: The Three Cycle View of Design Science Research. Scandinavian Journal of Information Systems 19(2), 87-92 (2007)

Hevner, A.R., March, S.T., Park, J., Ram, S.: Design Science in Information Systems Research. MIS Quarterly 28(1), 75-105 (2004)

Hovorka, D.S.: Incommensurability and Multi-paradigm Grounding in Design Science Research: Implications for Creating Knowledge. In: Pries-Heje, J., Venable, J., Bunker, D., Russo, N.L., DeGross, J.I. (eds.) IFIP WG. IFIP AICT, vol. 318, pp. 13-27. Springer, Heidelberg (2010)

IT Governance Institute 2010, Board Briefing on IT Governance, 2nd edn. (2010), http: / /www.itgi.org/

Jenkin, T., Webster, J., McShane, L.: An agenda for "Green" information technology and systems research. Information and Organization 21(1), 17-40 (2010)

Kanter, R.: Collaborative advantage - The art of alliances. Harvard Business Review 72(4), 96108 (1994)

Kim, Y., Hsu, J., Stern, M.: An Update on the IS / IT Skills Gap. Journal of Information Systems Education 17(4), 395-403 (2006)

Kuechler, W., Vaishnavi, V.: The emergence of design research in information systems in North America. Journal of Design Research 7(1), 1-16 (2008)

Kumar, K., van Dissel, H.G.: Sustainable collaboration - managing conflict and cooperation in interorganizational systems. MIS Quarterly 20(3), 297-300 (1996)

LaFrance, G.: Bridging the IT Skills Gap Through Industry and Academic Collaboration. Employment Relations Today 36(4), 25-30 (2010)

Lee, S., Koh, S., Yen, D., Tang, H.-L.: Perception gaps between IS academics and IS practitioners: an exploratory study. Information \& Management 40(1), 51-61 (2002)

Luftman, J.: Key Issues for IT Executives 2004. MIS Quarterly Executive 4(2), 269-285 (2005)

Luftman, J.N., Ben-Zvi, T.: Key Issues for IT Executives 2010: Judicious IT Investments Continue Post-Recession. MIS Quarterly Executive 9(4) (2010)

Magnusson, J.: Professional Analysts and the Ongoing Construction of IT Governance. International Journal of IT/Business Alignment and Governance 1(2), 1-12 (2010)

Malone, T.W., Crowston, K.: The interdisciplinary study of coordination. ACM Computing Surveys 26(1), 87-119 (1994)

Mathiassen, L.: Collaborative practice research. Scandinavian Journal of Information Systems 14(1), 57-73 (2002)

McBrayne, C.: 'Green IT' - the next burning issue for business. IBM Global Technology Services, London (2007)

Melville, N.P.: Information Systems Innovation for Environmental Sustainability. MIS Quarterly $34(1), 1-21(2010)$ 
Mohe, M.: What Do Consulting Firms Expect from Graduates and Universities? Empirical Insights from the German Consulting Market. In: Deelmann, T., Mohe, M. (eds.) Selection and Evaluation of Consultants, pp. 53-68. Rainer Hampp, Munich (2006)

Nguyen, T.N., Truong, Q., Buyens, D.: The Relationship between Training and Firm Performance: A Literature Review. Research \& Practice in Human Resource Management 18(1), 36-45 (2010)

Offermann, P., Levina, O., Schönnherr, M., Bub, U.: Outline of a design science research process. In: Proceedings of the 4th International Conference on Design Science Research in Information Systems and Technology (DESRIST), pp. 1-11. ACM, Philadelphia (2009)

Osorio, J., Bulchand, J.: Moving towards 2020: A Tentative Approach to ITEM. In: Tatnall, A., Kereteletswe, O.C., Visscher, A. (eds.) ITEM 2010. IFIP AICT, vol. 348, pp. 104-112. Springer, Heidelberg (2011)

Paul, D., Yeates, D., Cadle, J.: Business Analysis, 2nd edn. British Informatics Society Limited, Chippenham (2010)

Plice, R., Reinig, B.: Leveraging Alumni and Business Community Relations to Assess the Information Systems Curriculum. Journal of Education for Business 84(3), 142-150 (2009)

Pratt, J.A., Hauser, K., Ross, S.C.: IS Staffing During a Recession: Comparing Student and IS Recruiter Perceptions. Journal of Information Systems Education 21(1), 69-85 (2010)

Santana Tapia, R.: Assessing business-IT alignment in networked organizations, Ph.D., University of Twente (2009)

Sarkar, P., Young, L.: Managerial Attitudes Towards Green IT: An Explorative Study of Policy Drivers. In: Proceedings of PACIS 2009, Paper 95 (2009)

Schambach, T., Blanton, J.E.: The professional development challenge for IT professionals. Communications of the ACM 45(4), 83-87 (2002)

Schmidt, N.-H., Erek, K., Kolbe, L. M., Zarnekow, R.: Predictors of Green IT Adoption: Implications from an Empirical Investigation. In: Proceedings of AMCIS 2010, Paper 367 (2010)

Simonsson, M., Johnson, P.: Defining IT governance - a consolidation of literature. Royal Institute of Technology (KTH) - EARP Working paper MS103, Stockholm, Sweden (2006)

Smid, G.: Consultants' Learning within Academia: Five devices for the design of universitybased learning opportunities for management consultants. Studies in Continuing Education 23(1), 55-70 (2001)

Smith, H.A., McKeen, J.D.: IT in 2010: The next frontier. MIS Quarterly 5(3), 125-136 (2006)

Thompson, J.: Organizations in action. McGraw-Hill, New York (1962)

Tiwana, A., Konsynski, B.: Complementarities Between Organizational IT Architecture and Governance Structure. Information Systems Research 21(2), 288-304 (2010)

Topi, H., Valacich, J.S., Wright, R.T., Kaiser, K.M., Nunamaker Jr., J.F., Sipior, J.C., de Vreede, G.J.: IS 2010 - Curriculum Guidelines for Undergraduate Degree Programs in Information Systems. In: Association for Computing Machinery and Association for Information Systems (2010)

Van Grembergen, W.: From IT Governance to Enterprise Governance of IT: A Journey for Creating Business Value Out of IT. In: Cellary, W., Estevez, E. (eds.) Software Services for e-World. IFIP AICT, vol. 341, p. 3. Springer, Heidelberg (2010)

Vykoukal, J., Wolf, M., Beck, R.: Does Green IT Matter? Analysis of the Relationship between Green IT and Grid Technology from a Resource-Based View Perspective. In: Proceedings of PACIS 2009, Paper 51 (2009)

Watson, R.T.: Information Systems and environmentally sustainable development: energy informatics and new directions for the IS community. MIS Quarterly 34(1), 23-38 (2010)

Weill, P., Ross, J.W.: IT Governance: How Top Performers Manage IT Decision Rights for Superior Results. Harvard Business School Press, Boston (2004) 
Wieringa, R., van Eck, P., Steghuis, C., Proper, E.: Competences of IT Architects, 2nd edn., Netherlands Architecture Forum for the Digital World (2009)

Wilson, C., Guzdial, M.: How to make progress in computing education. Communications of the ACM 53(5), 35-37 (2010)

Wingreen, S.C., Lerouge, C., Blanton, J.E.: Structuring Training for IT Professionals and the Firm: An Application of the Q- Methodology. International Journal of Global Management Studies 1(1), 53-67 (2009)

Woodruff, A., Mankoff, J.: Environmental Sustainability. IEEE Pervasive Computing 8(1), 18$21(2010)$

Zarvić, N., Fellmann, M., Thomas, O.: Towards Dependency-based Alignment for Collaborative Businesses. In: Klink, S., et al. (eds.) Proceedings of EMISA 2010, GI edn., pp. 53-67. Gesellschaft für Informatik, Karlsruhe (2010a)

Zarvić, N., Seifert, M., Thoben, K.-D.: A task-resource dependency perspective on partner selection during the formation of networked business constellations. International Journal of Networking and Virtual Organisations (IJNVO) 7(5), 399-414 (2010b) 